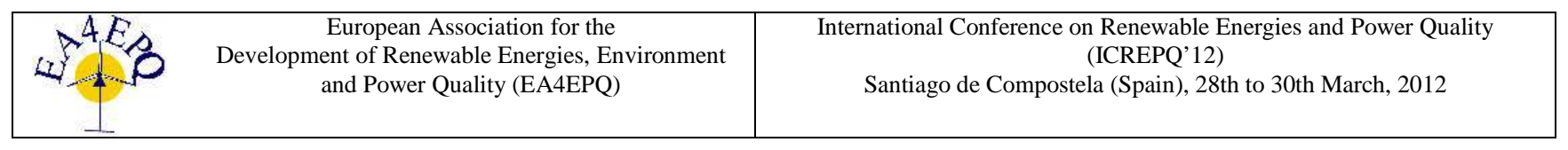

\title{
Influence of small solar power plants on power quality
}

\author{
S. Seme, J. Voh, J. Voršič \\ University of Maribor \\ Faculty of Electrical Engineering and Computer Science \\ Smetanova 17, 2000 Maribor (Slovenia) \\ Phone: +386 2220 7050, Fax number: +386 2252 5481, e-mail: vorsic@uni-mb.si
}

\begin{abstract}
The solar power plants are usually connected to the distribution network in node with transformer. Small, mini and micro solar power plants are connected as real dispersed production in the middle or at the end of line as consumers. This paper describes measurements, according to standard SIST EN 50160, at $274 \mathrm{~m}$ long line, fed at one side from $20 / 0,4 \mathrm{kV}$ transformer and at the other side from small solar power plant and in between are 15 users (houses).
\end{abstract}

\section{Key words}

Dispersed production, small solar power plants, SIST EN 50160, measurements

\section{Introduction}

Slovenia has at least 10 times less classic energy resources as other countries in the World. Situated in front of Alps Slovenia has quite a lot of precipitation which offers a lot of possibilities to use existing hydro potential, solar energy and biomass.

Nowadays we have to assure independency at least with electric energy supply similar as we had a goal to be selfsufficient in providing food some years ago. Projection of consumption and production shows quite opposite, as is shown in Fig. 1 [1].

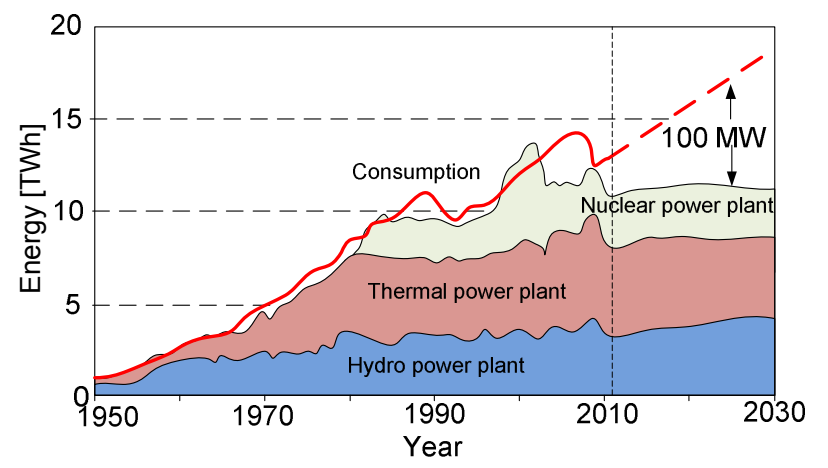

Fig. 1. Covering electric energy consumption in Slovenia.
Increased use of renewable sources and efficient energy use are most important options to cover consumption with production together with building new large power plants. Solar energy can be exploited in two ways: with thermal systems and by using photon effect [2].

Photon effect is used in photosynthesis (generally called bioconversion) and to produce biomass, for photochemical synthesis and for photovoltaic effect in which solar radiation is directly converted in electric energy in semiconductor "solar cells".

In spite of medium high geographic latitude (radiation angle of incidence) is in Slovenia large number of sunny days and therefore a lot of options to use all three possibilities of exploiting solar radiation [3]. Hydro power plants are not easy to install into space while there is no problems with building solar power plants on roofs of new or already built objects. The table I shows number and power of grid connected solar power plants in Slovenia.

Table I. - Number and power of grid connected solar power

\begin{tabular}{|l|r|r|r|}
\hline Year & $\begin{array}{c}\text { Number } \\
\text { of PV } \\
\text { plants }\end{array}$ & $\begin{array}{c}\text { Total } \\
\text { power } \\
{[\mathrm{kW}]}\end{array}$ & $\begin{array}{c}\text { Part in energy } \\
\text { consumption } \\
{[\% \mathbf{\% o}]}\end{array}$ \\
\hline 2003 & 1 & 4,5 & 0,000375 \\
\hline 2004 & 1 & 7,5 & 0,000625 \\
\hline 2005 & 6 & 73,9 & 0,006158 \\
\hline 2006 & 8 & 117 & 0,009750 \\
\hline 2007 & 14 & 397 & 0,033083 \\
\hline 2008 & 57 & 1060 & 0,088333 \\
\hline 2009 & 202 & 7240 & 0,603333 \\
\hline 2010 & 330 & 18440 & 1,536667 \\
\hline 2011 & 459 & 34150 & 2,845833 \\
\hline sum & 1078 & 61490 & 5,124167 \\
\hline
\end{tabular}

Government of Republic of Slovenia has decided, similar as in some other countries, to encourage electric energy production in solar power plants with subventions or by buying electric energy from qualified producers at higher price [4] and [5]. Prices and bonuses for buying electric energy from solar power plants differ according to power 
plants nominal power. In accordance to that the number of power plants is rising [6].

\section{Distribution line}

Power plant is connected to low voltage electric network via low voltage cable NAYY-O 4x70+2,5 0,6/1 kV lead to the pillar of low voltage network and fed from the 20/0,4 kV transformer station.

Measurements [7] were performed according to standard SIST EN 50160 [8] for a week at three phase distribution line shown in figure 2. All together seven instruments were used measuring frequency, voltage level, voltage deviation, fast changes in voltage, voltage sags, overvoltages, voltage unbalances and harmonic voltages. Measuring points were at power plants, low voltage side of transformer and five larger consumers (figure 2).

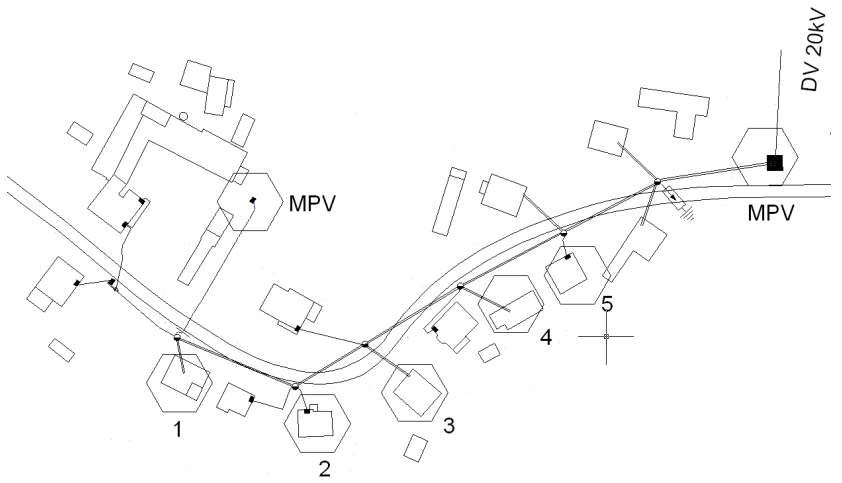

Fig. 2. Three phase distribution line fed from two sides.

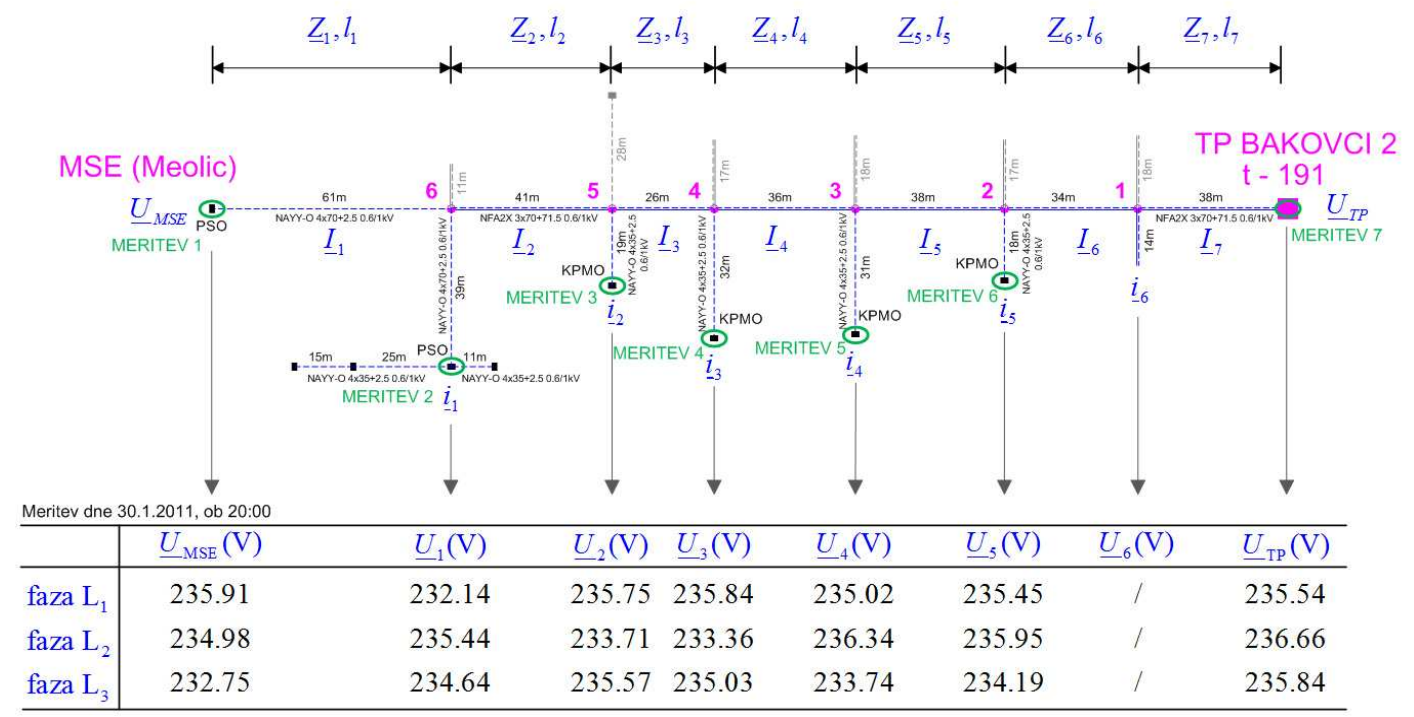

Fig. 3. Measured voltages for January $30^{\mathrm{TH}} 2011$ at 8:00 PM.

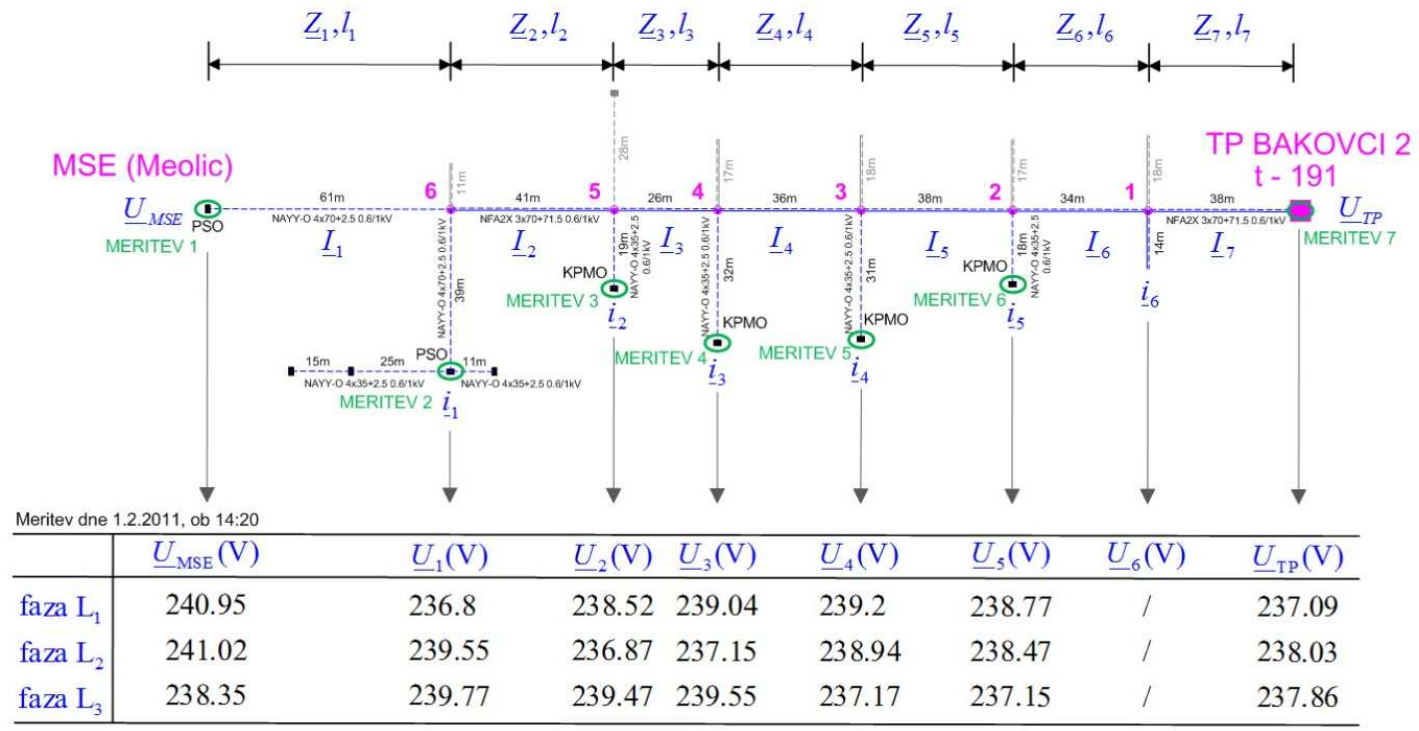

Fig. 4. Measured voltages for February $1^{\mathrm{ST}} 2011$ at 2:20 PM. 


\section{Measurements}

We payed most attention to voltage level [9] due to fear that power plant at the end of distribution line would damage voltage profile. Figure 3 shows values of measured voltages for January $30^{\mathrm{TH}} 2011$ at 8:00 PM when small solar power plants was not feeding energy into the grid. Individual voltages of average 10-minute effective values for phases $\mathrm{L}_{1}, \mathrm{~L}_{2}$ and $\mathrm{L}_{3}$ are shown. Values are obtained from measurement data, exported from programme CODAM Plus and imported to MS Excell.

Measured voltages for February $1^{\text {ST }} 2011$ at 2:20 PM when small solar power plant was feeding the grid with energy are shown in figure 4. Individual voltages of average 10-minute effective values for phases $L_{1}, L_{2}$ and $\mathrm{L}_{3}$ are shown. Values are obtained from measurement data, exported from programme CODAM Plus and imported to MS Excell.

Voltage deviations from nominal (agreed) voltage $U_{\mathrm{c}}$ are smaller from class of used instruments at individual measurement points and phases and do not exceed allowed deviation values at no point (figure 5). Largest deviations were (negative) at evening peeks.
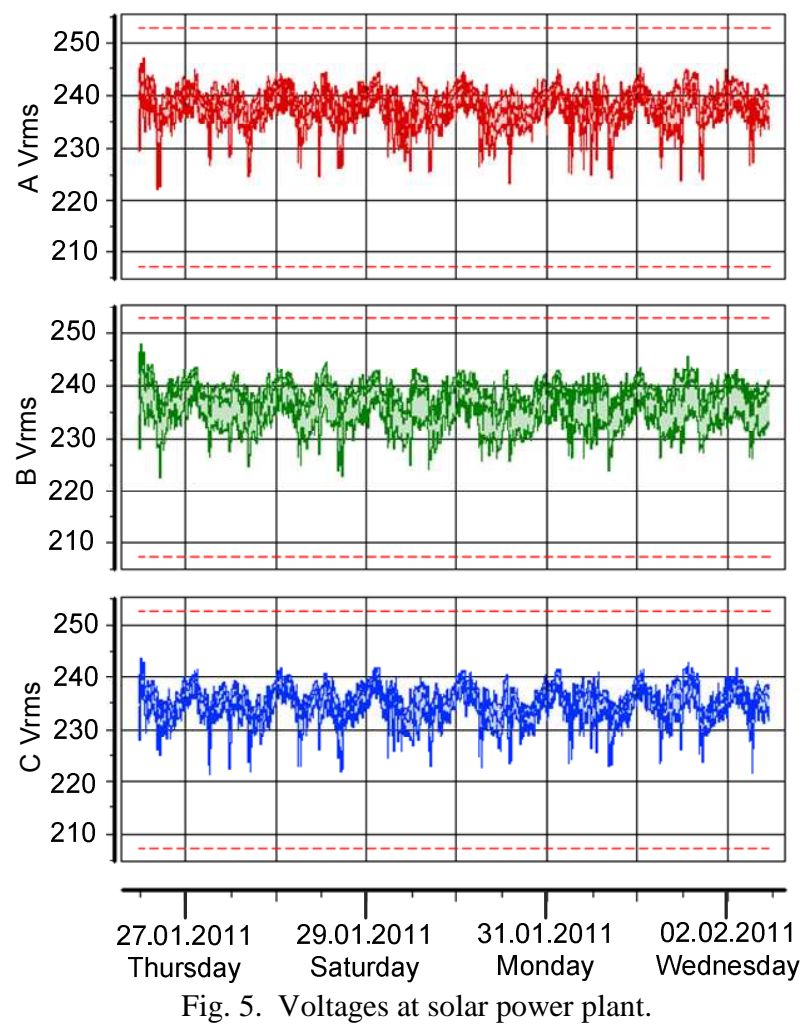

Voltage deviations from nominal (agreed) voltage $U_{\mathrm{c}}$ are even smaller at the transformer station (figure 6) and never exceed allowed deviation values.

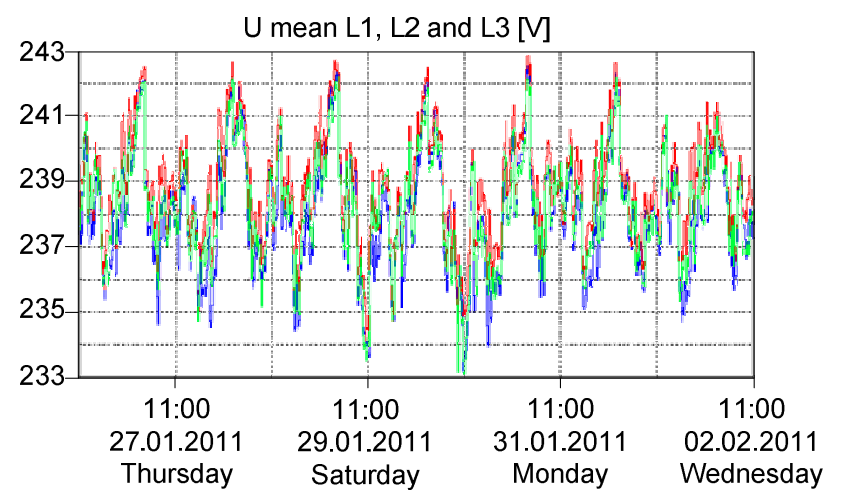

Fig. 6. Effective values for phases L1, L2 and L3 at the transformer station.

Largest voltage Total Harmonic Distortion (THD) was measured at solar power plant $(2,39 \%$, figure 7$)$ together with long term flicker $P_{\mathrm{lt}}(1,30 \%$, figure 8$)$. Both values were decreasing towards transformer station $(\mathrm{THD}=1,9 \% ; \mathrm{Plt}=0,26 \%)$.

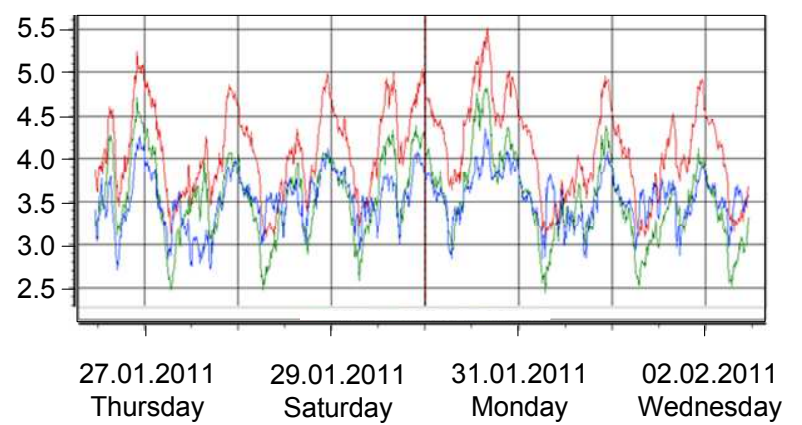

Fig. 7. 10 minutes effective values of voltage $\mathrm{THD}_{u}$.

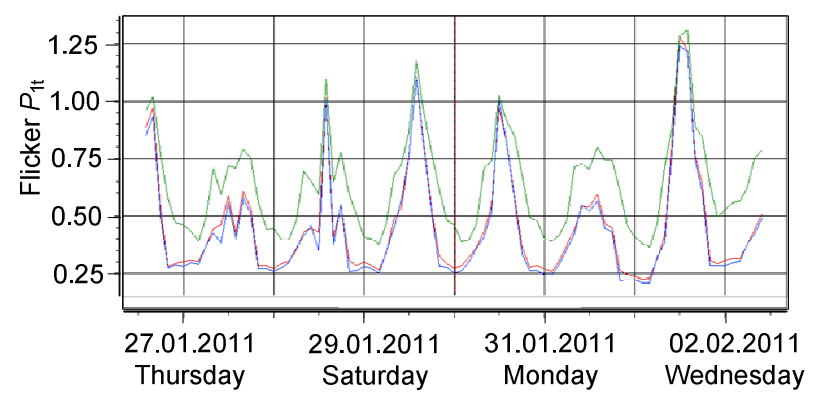

Fig. 8. Long term flicker $P_{\mathrm{lt}}$.

\section{Conclusion}

We have decided to perform measurements at distribution line due to fear that dispersed production (power plant at the end of distribution line) would damage voltage profile of such line. We had quite some difficulties finding such distribution line. Energy Law [10] enables every consumer and producer of electric energy access to the grid and distribution companies define with their regulations the way and place of connection [11]. For producers (power plants) as connection point is usually defined node with the transformer where power plant has less influence.

Measurements were performed according to standard SIST EN 50160 for a week at three phase distribution line. 
Voltage deviations from nominal (agreed) voltage $U_{\mathrm{c}}$ are smaller from class of used instruments at individual measurement points and phases and do not exceed allowed deviation values at no point (figure 5). Largest deviations were (negative) at evening peeks.

Largest voltage Total Harmonic Distortion (THD) was measured at solar power plant $(2,39 \%)$ as random value independent from production or consumption. Just the opposite the long term flicker $P_{\text {lt }}$ occurred always when power plant was producing energy but was not largest at maximum power $\left(P_{\mathrm{lt}}(P=8,7 \mathrm{~kW})=1,02 \%\right.$; $\left.P_{\mathrm{lt}}(P=7,4 \mathrm{~kW})=1,30 \%\right)$. Both voltage Total Harmonic Distortion $\left(\mathrm{THD}_{u}\right)$ and long term flicker $P_{\mathrm{lt}}$ values were decreasing towards transformer station (stronger supply point).

Research will be continued in two directions: we will locate more distribution lines with dispersed production and perform measurements at medium voltage due to connection of larger power plants.

\section{References}

[1] M. Pirc, Potenciali uvedbe upravljanja z energijo v NEK, Magistrsko delo, UM FE, Krško 2011

[2] J. Voršič, A. Orgulan, Pretvarjanje v električno energijo, UM FERI, Maribor, 1996.

[3] D. Kastelec, J. Rakovec, K. Zakšek, Sončna energija v Sloveniji, Založba ZRC, Ljubljana, 2007.

[4] Vlada RS, O cenah in premijah za odkup električne energije od kvalificiranih prizvajalcev električne energije, Uradni list RS, št. 65/2008

[5] I. Šeneker, Oskrba povprečne slovenske hiše z električno energijo, diplomsko delo, UM FERI, Maribor 2009

[6] http://www.zsfi.si/

[7] T. Mastnak, Obratovanje male sončne elektrarne v nizkonapetostnem omrežju, Diplomsko delo, UM FERI, Maribor 2010

[8] CENELEC, Slovenski standard SIST EN 50160, druga izd., 2001

[9] F. Žlahtič, D. Matvoz, Motnje in motenja v elektroenergetskih omrežjih, Elektrotehniška zveza Slovenije, Ljubljana, 2003.

[10] Vlada RS, O cenah in premijah za odkup električne energije od kvalificiranih prizvajalcev električne energije, Uradni list RS, št. 65/2008

[11] SODO, Sistemska obratovalna navodila za distribucijsko omrežje električne energije, Uradni list RS, št. 41/2011 